on hop until frost overtakes the species in all conditions and sweeps from the hop yards all individuals alike, perpetuating in the egg state those only which reached the sexual condition on the plum.

(9) Eac's parthenogenetic female is capable of producing on an average 100 young (the stem-mother probably being more prolific) at the rate of one to six, or an average of three per day, under favourable conditions. Each generation begins to breed about the eighth day after birth, s) that the issue from a single individual easily runs up, in the course of the summer, to trillions. The number of leaves (700 hills, each with two poles and two vines) to an acre of hops, as grown in the United States, will not, on the average, exceed a million before the period of blooming or burring; so that the issue from a single stemmother may under favouring circumstances blight hundreds of acres in the course of two or three months.

(Io) While meteorological conditions may materially affect the increase and power for injury of the species, these are far more truly predetermined and influenced by its natural enemies, many of which have been studied and will be described.

(II) The slight colorational differences, as also the structural differences, including the variation in the cornicles on head and basal joints of antennæ, whether upon plum or hop, are peculiarities of brood, and have no specific importance whatever.

(I2) The exact knowledge thus gained simplifies the protection of the hop plant from Phorodon attack. Preventive measures should consist in destroying the insect on plum in early spring where the cultivation of this fruit is desired, and the extermina tion of the wild trees in the woods wherever the hop interest is paramount; also in avoiding the introduction of the pest into new hop countries in the egg state upon plum cuttings or scions. Direct treatment is simplified by the fact that the careful grower is independent of slovenly neighbours, infection from one hop yard to another not taking place.

Experiments still under way have shown that there are many effective remedies, and that the ordinary kerusene emulsion diluted with twenty-five parts of water and sprayed with the cyclone nozzle, or a soap made by boiling one pound of pure potash in three pints of fish oil and three gallons of water, and this dissolved in eight gallons of water, and sprayed in the same way, are thoroughly effectual remedies, and leave the plant uninjured. The former costs 75 cents, the latter 30 cents, per acre, plus the time of two men for thee hours, plus appliances. The object of further experimentation now being carried on is to simplify and reduce the cost of these last to a minimum. As they consist, however, essentially of a portable tank and a forcepump with hose and spraying attachment, which, together, need not involve a greater first outlay than 5 dollars to 10 dollars, and as every American hop grower can afford to expend the larger sum for the protection of a single acre, there is no longer any excuse for allowing this pest to get the better of us.

It is not my purpose, however, to enter into aphidicide details in this communication, which I will conclude by brief reference to the bearings of these discoveries in America on the problem in Great Britain. The most c.smprehensive and satisfactory review of the knowledge possessed on the subject in England that has come to my notice, is that by my esteemed friend and correspondent, Miss Eleanor A. Ormerod, Consulting Entomologist of your Royal Agricultural Society, in her "Report of Observations of Injurious Insects," \&c., made in 1885 . So far as her own careful observations are concerned, they fully accord with the facts here set forth; but on the authority of others, and especially on the evidence of $\mathrm{Mr}$. C. Whitehead, who reported finding young lice and large viviparous females on hop shoots as early as March 29, and that of Mr. A. Ward, who experimented with surface dressings nexr Hereford, Miss Ormerod concludes that attack on the hop begins in spring from wingless females which come up from the hop hills, and, as a corollary, that dressings to prevent such ascent are strongly to be recommended. It is quite within the range of possibility, and what is known of aphid life, that where the winters are mild, with scarcely any frost, this Phorodon may continue on the hop from one year to another in the parthenogenetic condition. If such is ever the case in England, you have a solnewhat different set of facts to deal with here from what we have in America. But for the reason; already stated in abstract, from many other detailed observations which it would be tedious to record here, as well as from the ease with which erroneous conclusions are arrived at in entomological matters of this kind, where not checked and proved by the most competent and careful study, I shall be inclined to believe that the facts in England are essentially the same as I have found them in America, until convincing and trustworthy evidence to the contrary be forthcoming. Mr. Whitehead may have had another species under observation, and Mr. Ward's surface dressings may have acted by repelling the winged female migrating from Prunus, in the same way that buckwheat sown among the hops is believed to do with us.

\section{EDUCATION IN GERMANY.}

TIHE following letter appeared in the Tumes on the Ioth inst. : -

SIR, - I should be glad if you could find space in your columns for some remarks on the state of education i, Germany. I have just completed a short tour in this country, mainly to inquire into its educational system, especially with reference to primary and technical schools. England has at last roused herself to the necessity for technical education.

The Bill, which was unhappily crowded out last session, will be reproduced next year, and, I trust, expanded to larger dimensions. It will contain, I hope, a clause for the establishment of evening continuation schools, for which object I gave notice of an amendment last session. My trip to Germany has been chiefly taken to learn what is doing here in this direction, and what is the drift of educated German opinion. With your permission I will briefly summarize my impressions. I premise by observing that each St ste of the German Empire manages its own education, and that the laws and regulations differ somewhat, so that general statements referring to all Germany cannot be made without qualifications. I will not weary your readers, however, by going into details respecting each State, but place broadly before them the general features of German education.

The salient fact which strikes all observers is the universality of good education in this cuntry. There is no such thing as an uneducated class; there are no such thing;, speakin $r$ broadly, as neglected and uncared-for children. All classes of the community are better educated than the corresponding ones in our country; and this applies quite as much to p:imary as to secondary education. Nothing struck me more th in the general intelligence of the humbler working classes. Waiters, porters, guides, \&c., have a knowledge of history, geography, and other su'jects far beyond that possessed by corresponding classes it England, and the reason is not far to seek. The whole population has long been passed through a thorough and comprehensive system of instruction obligatory by law and far more extended than is given in our elementary schools. I went through several of these schools and observed the method of teaching, which was simply admirable. The children are not crammed, but are taught to reason from the earliest stages. The first object of the teacher is to make his pupils comprehend the meaning of everything they learn, and to carry them from stage to stage so as to keep up an eager interest.

I siw no signs of weariness or apathy among either teachers or scholars. The teaching was all vivi $v j c$; the teacher always standing beside the blackboard and illustrating his subject by object-lessons. The instruction wa; through the eye and hand as well as the ear, and question and answer succeeded so sharply as to keep the whole class on the qui vive. The teachers are, as a body, much bettei trained than in England, and seem to be enthusiasts in t'eir calling, and the school holds a far higher position in the social economy of the country than it does with us. What $\mathrm{I}$ am saying here applies equally to Switzerland as to Germany, and for educational purposes Zurich will compare with any part of this empire. The main advantage, however, that primary education has in Germany over England lies in the regularity of attendance and the longer period of school life. There is none of the difficulty of getting children to school that exists in England; the laws are very rigid and permit no frivolous excuses, and, what is even more important, the people entirely acquiesce in the laws, and are inclined rather to increase than relax their rigour. It is well known that in London and all our great cities a large part of the population seek to avoid school attendance by every means in their power, and consequently the attendance is most irregular. There is very little of this in Germany; at least I have not found it so. Then in our country a great portion of our children are withdrawn altogether from school, after passing the fourth or fifth standard, at the age of eleven or twelve, whereas in Germany almost 
everywhere attendance is compulsory until fourteen for boys, though in some places girls are allowed to leave at thirteen.

This last point is the one I wish to emphasize. The great defect-I might almost call it the fatal defect-of our system is that it stops just at a time when real education should begin. It allows a child to leave school at an age when its learning is soon forgotten and its discipline effaced. It is hardly too much to say that the two years' additional training the German child receives in the elementary school, doubles its chance in life as compared with the English child.

But this is not all. The Germans are rapidly developing a system of evening continuation classes which carry on education for two or three years longer. In Saxony the boys who leave the primary school, if they do not go to the higher schools must attend for three years longer-say, until they are seventeencontinuation classes for at least five hours per week. But teaching is provided for them, and they are encouraged to attend, twelve hours per week. So complete is this system that even the waiters at the hotels up to the age of seventeen attend afternoon classes, and are taught one or two foreign languages. I take Saxony as one of the most advanced States; but the law is much the same in Würtemburg and Baden, and the system is found to work so well that it is in contemplation to extend it to all the States in the German Empire, and Austria will probably follow suit. This is confidently expected to happen in the course of 1888. I may state as an undoubted fact that in Germany and Switzerland, and I believe in some other Continental countries, the opinion is ripening into a conviction that the education, even of the poorest class, should be continued in some form or another ta the age of sixteen or seventecn. They find by experience that wherever this is adopted it gives an enormous advantage to the people in the competition of life, and, above all, trains them to habits of industry and mental application. I believe it is owing to this system of thorough education that Germany has almost extinguished the pauper and semi-pauper class, which is the bane and disgrace of our country.

Wherever I have gone I have inquired how they deal with the ragged and squalid class of children, and $I$ have been told in every city I visited-in Zurich, Stuttgart, Nuremberg, Chemnitz, Uresden, and Berlin-that such a class practically does not exist. I do not mean that there is not poverty and plenty of it in Germany. Wages are much lower than in England, and many have a hard struggle to live. But there does not seem to exist to any extent that mass of sunken, degraded beings who with us cast their children upon the streets, or throw them on the rates, or leave them to charity. Some half-a-million of children in the United Kingdom are dependent, more or less, on the alms or the rates of the community, and probably another half-million are miserably under-fed and under-clad. Nothing to correspond with this exists in Germany. The poorest people here would be ashamed to treat their children as multitudes do with us. Indeed, I have not seen since I left home a single case of a ragged or begging child. I repeat that the great cause of this both in Germany and Switzerland is the far greater care they have taken of the education of the children for at least two or three generations, whereas we have only taken the matter up seriously since 1870 , when Mr. Forster's great Act was passed.

Let us cuntrast the general condition of our London children, for instance, at the age of fifteen or sixteen, with that of the same class in Berlin or Dresden or Chemnitz. With us ninetenths of the chidren have long since left school, and a too large proportion of them are receiving no training but the coarse and brutalizing education of the streets. Most of them retain little of what they have learnt at school, except the power to read the " penny dreadful," which stuffs their minds with everything a child should not know. They are to a very large exten adepts in profane and obscene language, and are frequenters of the public-house, the "penny gaff," and such like amusements; a great many of them are learning no useful trade or calling, but are drifting helplessly into the class of wretched, ill-paid, casual labourers. Very many of them marry before they are twenty, and are soon the parents of a numerous progeny, half-starved and stunted both in body and mind. Compare, or rather contrast, this with Germany. At fifteeen or sixteen a great part of the children are still under excellent instruction. Exceedingly few are to be found roaming about the streets. They are prohibited, at least in some parts of Germany, from entering the public houses (except with their parents) until the age of seventeen, and I am told are everywhere prohibited from smoking until sixteen. In fact, there are, both by law and public sentiment, barriers placed against the corruption of the young which do not exist in England.

No country has ever suffered more from the abuse of the idea of individual liberty than England has done. Owing to this overstrained idea we did not get compulsory education until long after the advanced nations of the Continent, and still we are far behind them in the care we take of our children. It is intolerable that this state of things should continue longer. Democratic government everywhere insists upon good education, and expects each citizen to fulfil his duties to the State.

Public opinion in our country will certainly insist, and that before long, that we shall not be for ever disgraced with a residuum of the most drunken, demoralized, and utterly incapable population to be found in any modern State. It will insist that some time be spared for the solution of this vital question from the wrangles of party politics and the party recriminations of party leaders. When one sees what a poor country like Germany has done to raise its people in spite of the conscription and three years' compulsory military service, in spite of frequent and exhausting wars from which our island home has been free, one has grave doubts whether our system of party government is not a failure.

Certainly we waste on barren conflicts and wordy strife fas more time than other nations do in the conduct of their affairs. They direct their energies with business-like precision to supply the exact needs of the people, we fritter away our enormous political energy in fruitless party contests which every year degrade Parliament lower and lower, and make it less and less fit for the practical work of governing the nation.

One thing seems certain. Unless we can give more attention to the vital questions which concern the welfare of the masses our country must go down in the scale of nations. No honest observer can doubt that in many respects the Germans are already ahead of us, and they are making far more rapid progress than we are. They are applying technical science to every department of industry in a way that Englishmen have little idea of. Their polytechnics and their practical technical schools are far ahead of anything we possess in England, the leaders of industry are far better trained, the workmen are better educated and far more temperate and thrifty than ours are. Wherever the Germans and English are coming into competition upon equal terms the Germans are beating us. This is not because the Germans have greater natural power. I believe the British race is the more vigorous naturally. But they are organized, disciplined, and trained far better than we are. They bring science to bear upon every department of the national life, whereas we, up till lately, resented all State interference, and so exaggerated the doctrines of freedom as almost to glory in our abuses.

There is much more that $I$ might say if space permitted; but it will not do to trespass further on your indulgence. I will only add in conclusion that England must wake up, and that immediately, to the necessity of a far more thorough and practical system of education, else she will lose the great place she has hitherto held in the world's history.

Berlin, October 4. I am, Sir, yours faithfully,

\section{THE BRITISH ASSOCIATION.}

\section{Section B-Chemical Science.}

The Atomic Weight of Gold, by J. W. Mallet, F.R.S.Attention is called to the importance of correct determinations of atomic weights by different experimenters, and especially the elimination of "constant errors." Considering the desirability that all such values should be connected as directly as possible with hydrogen, a method is described by which this may be done in the case of gold. A known weight of zinc is dissolved in dilute sulphuric acid, and the hydrogen evolved is measured. A solution of bromide or chloride of gold is then treated with zinc more than sufficient to precipitate the whole of the gold, the residual zinc being determined by the hydrogen evolved on treatment with sulphuric acid. The difference in volume of hydrogen obtained gives a direct means of calculating the atomic weight of gold. The author described various experimental precautions that had been taken in measuring the gas.

The Atomic Weight of Zirconium, by Dr. G. H. Bailey.-The previous determinations of the atomic weight of this element 